\title{
De nacht als onontgonnen onderzoeksterrein
}

INLEIDING Ilse van Liempt \& Irina van Aalst

's Nachts gebeuren er allerlei interessante dingen in de stad. Toch wordt er in zowel onderzoek als in beleid weinig expliciete aandacht geschonken aan dit specifieke tijdsmoment. AGORA zet haar nachtbril op en bekijkt de stad dit keer vanuit een andere dimensie.

Als we deze introductie schrijven is het Amsterdamse Dance Event (ADE) in volle gang. 300.000 danceliefhebbers, waarvan ongeveer 60.000 toeristen uit heel Europa, genieten van de vele feesten in de stad. In vijf dagen tijd zijn er op 75 verschillende locaties 300 events te bezoeken en 2.000 dj's te beluisteren. De stad wordt getransformeerd en plekken krijgen een andere betekenis en uiterlijk dan normaal. Voor het statige Muziekgebouw aan het 't IJ stond dit weekend bijvoorbeeld een rij met danceliefhebbers die bijna de hele kade besloeg. Een publiek met een andere kledingstijl dan de doorsnee klassiek concertbezoeker, en met een duidelijk ander consumptiepatroon.

De Nederlandse dance-industrie draait goed. Uit onderzoek blijkt dat de dj's, festivals en organisatiebureaus gezamenlijk tegenwoordig meer dan een half miljard omzetten. Het economische belang van dancemuziek is de laatste jaren enorm gegroeid, vooral door de explosieve stijging van het aantal festivals en het aantal dj-optredens in het buitenland. Steeds vaker kopiëren Nederlandse organisaties concepten naar het buitenland. De 'Sensationfeesten' van ID\&T vinden bijvoorbeeld al plaats in ruim zestig landen. Dance is een belangrijk exportproduct geworden voor Nederland. Wereldwijd wordt het economische belang van dancemuziek op 2,7 miljard euro geschat en staat Nederland op de tweede plaats. Het belang van dance als Nederlands exportproduct blijkt uit het feit dat sinds januari 2013 dance officieel is opgenomen als onderdeel van de topsector creatieve industrie. In dit topsectorenbeleid is dance geformuleerd als een van de acht belangrijkste economische pijlers waar de Nederlandse overheid zich op richt.

\section{Opkomst van de nachteconomie}

Alhoewel een gevarieerd aanbod van restaurants, cafés en clubs van oudsher is verbonden met de stad, hebben binnensteden zich de afgelopen jaren steeds meer ontwikkeld tot bruisende uitgaanscentra en wordt het publiek steeds jonger. Ninette van Hasselt van het Trimbos Instituut geeft in haar bijdrage aan dit themanummer een historisch overzicht van hoe de transformatie van uitgaansgebieden en het bijbehorende publiek zich heeft voltrokken. Sinds de deïndustrialisatie en de daarmee samenhangende veranderingen in de economische basis van steden richten stadsbestuurders steeds meer de aandacht op consumptie en vrijetijdsbesteding. Oude fabrieksgebouwen zijn omgebouwd tot feestlocatie of poppodium en de werkgelegenheid in de uitgaanssector groeide explosief. Horecaondernemers richten zich tegenwoordig op specifieke groepen met attractieve acties, zoals 'happy hours' en 'student-only nights'.

Maar het blijft niet altijd gezellig. Er gebeuren in de nacht ook dingen die het daglicht niet kunnen verdragen, zoals bedreigingen, vernielingen en overmatig drank- en druggebruik. De consumptie van geestverruimende middelen is één van de belangrijkste pijlers van deze 'economy of pleasure'. Criminoloog Ton Nabben gaat in zijn bijdrage voor AGORA uitvoerig in op trends in het drugsgebruik in het Amsterdamse uitgaansleven.

\section{De economische meerwaarde van de nachteconomie staat in schril contrast met de overwegend negatieve berichtgeving.}




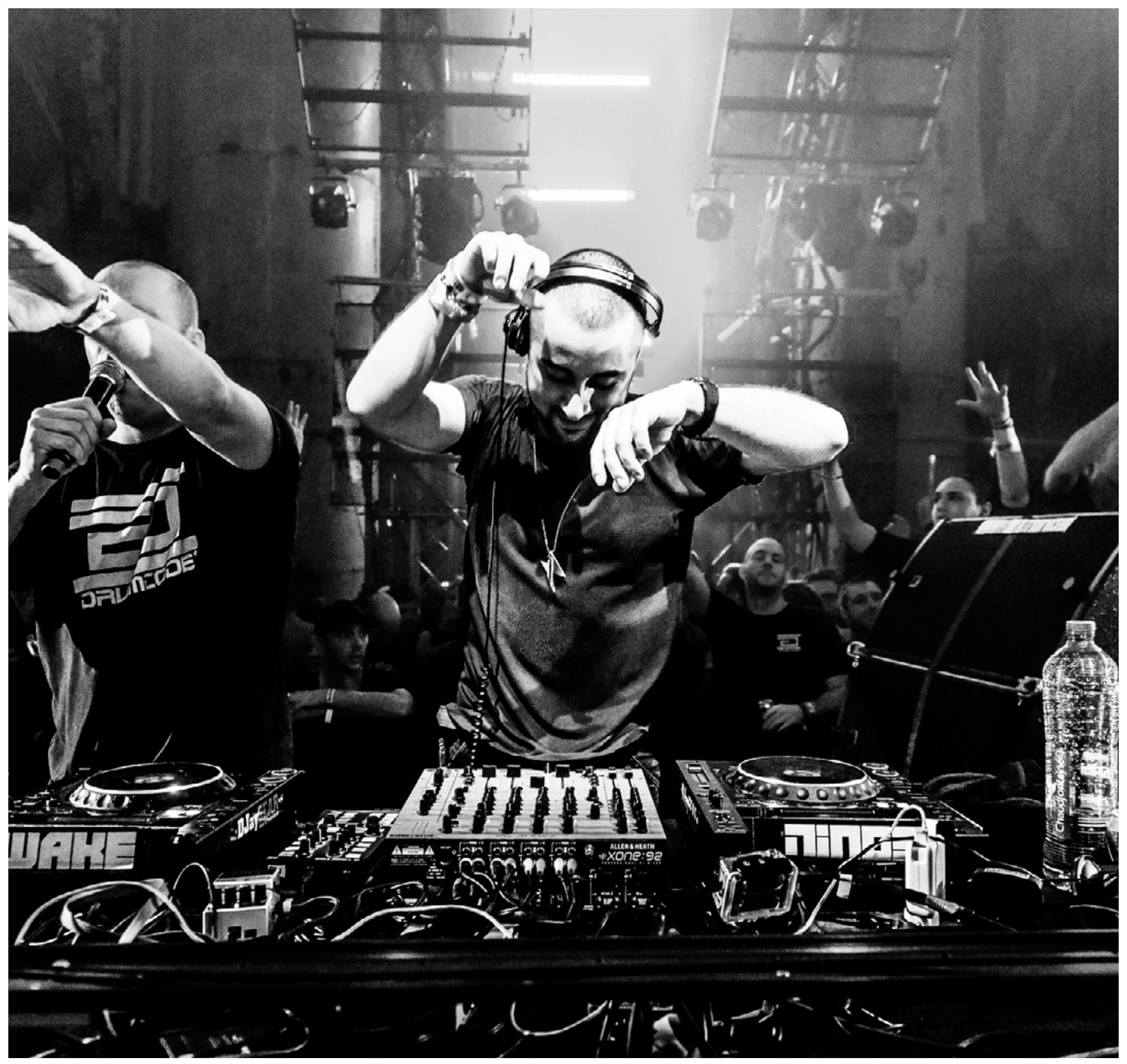

Tijdens het Amsterdam Dance Event genieten 300.000 dance liefhebbers van 300 events en 2.000 djs. De stad wordt tijdelijk getransformeerd en het wordt zichtbaar duidelijk hoe groot de dance-industrie momenteel is. Foto: Photo-Company.nl

De cijfers die de economische meerwaarde van de nachteconomie benadrukken staan in groot contrast met de overwegend negatieve berichtgeving over de stedelijke nacht in zowel onderzoek als de media. Engeland is koploper op het gebied van onderzoek naar de 'Night Time Economy'. Maar binnen dit Britse onderzoek naar uitgaan gaat de meeste aandacht uit naar criminaliteit en overlast. Lodewijk Brunt laat in zijn artikel 'Nachtblindheid' op overtuigende wijze zien hoe deze eenzijdige interesse in onderzoek naar uitgaan een breder verschijnsel is. De nacht als geheel is een onontgonnen onderzoeksterrein. Zelfs binnen klassieke stadsetnografieën over thema's waar de nachtelijke dimensie een uitermate belangrijke rol speelt, wordt er weinig theoretische aandacht geschonken aan deze specifieke tijdsdimensie.

Berichtgeving in de media over uitgaan is ook erg eenzijdig. Zij richten zich, zoals te verwachten van media, met name op de excessen. Jongeren zouden zich massaal in coma zuipen en uitgaan gerelateerde overlast en geweld schrikbarend toenemen. Denk aan de mishandeling van een man uit Eindhoven die na het uitgaan, op weg naar huis een groep jongens tegenkwam die hem op brute wijze mishandelde. Dit soort uitbarstingen van geweld gebeuren vaker in uitgaansgebieden, maar tegenwoordig zijn ze eerder en vaker algemeen bekend. Deze mishandeling werd gefilmd door beveiligingscamera's en de beelden uitvoerig gedeeld via sociale media door de politie en door bezorgde en verontruste burgers/ouders. We weten overigens erg weinig af van de beleving van veiligheidsmaatregelen door bezoekers van uitgaansgebieden. In de bijdrage van Van Aalst, Arets en Brands staat dit perspectief centraal. Zij laten op methodologisch innovatieve wijze, aan 
de hand van 'Customer Journey Maps', zien hoe ervaringen van onveiligheid en ongemak onderdeel uitmaken van een avond uit. Op de achterkant van dit themanummer is een visuele weergave van de resultaten van dit onderzoek te vinden.

\section{Regulering van de nacht}

Als we kijken naar de regelgeving rondom uitgaan valt op dat er steeds meer de nadruk wordt gelegd op het tegengaan van asociaal gedrag en het voorkomen van excessen. In de academische literatuur wordt dit verschijnsel ook wel omschreven als de 'fun-disorder paradox'. Aan de ene kant willen jongeren plezier maken, en wordt deze nachtelijke consumptie door veel stadsbesturen tegenwoordig extra gestimuleerd als onderdeel van de stedelijke economie. Aan de andere kant resulteert het stimuleren van plezier in de nacht regelmatig in gedrag wat niet 'door de beugel kan' en wordt juist daar concreet beleid voor gemaakt.

Ilse van Liempt geeft in haar artikel een kijkje in de laatste trends op het gebied van regulering van de nacht in haar artikel. Rotterdam is een interessante casus omdat deze stad bekend staat om haar laboratoriumfunctie en haar pragmatische aanpak. Als er nieuwe initiatieven zijn schuwt Rotterdam niet om ze uit te proberen en ze doet het meestal ook gelijk goed. Zo heeft Rotterdam de meeste bewakingscamera's in de openbare ruimte en het meeste effectieve systeem van uitkijken, 24 uur per dag worden alle camera's van de gemeente 'live' bekeken in de 'control room'. De vierentwintiguurseconomie zie je in deze stad dus ook terug in het beveiligingsapparaat.

Van Liempt besteedt in haar artikel ook aandacht aan de nationale beleidscontext. Het beleid 'Veilig en Gezond Uitgaan' is een relatief nieuw beleidsterrein. Het feit dat deze termen zichzelf tegenspreken laat meteen zien hoe complex het vraagstuk van regulering van de nacht is. Uitgaan is alles behalve gezond en veilig en wil dat ook vaak niet zijn. De vraag is dan ook hoe zorg je ervoor dat stedelijke uitgaansgebieden aantrekkelijke plekken zijn voor haar bezoekers om te experimenteren, maar tegelijkertijd veilig en verantwoordelijk gedrag stimuleren? Of, zoals Rien van der Steenoven, stadsmarinier in het centrale uitgaansgebied van Rotterdam, zich iedere avond afvraagt: hoe kun je het plezier in de stad erin houden? Wij interviewden Rien van der Steenoven voor dit themanummer.

\section{Herwaardering van de nacht}

Buurtbewoners spelen een steeds belangrijkere rol bij de totstandkoming van regelgeving in uitgaansgebieden. Het aantal klachten van geluidsoverlast van horeca door omwonenden neemt de laatste jaren schrikbarend toe. Valerie De Craene bespreekt in dit themanummer het boek van Laam Hae 'The Gentrification of Nightlife and the Right to the City' over de relatie tussen gentrification en het stedelijke nachtleven. Dit boek speelt zich af in New York, maar in Nederland zijn soortgelijke ontwikkelingen gaande. Aan de ene kant wordt het nachtleven gebruikt om bepaalde buurten op de kaart te zetten. Amsterdam heeft bijvoorbeeld onlangs een aantal horecavergunningen afgegeven voor 24 uur. Bijna al deze horecagelegenheden bevinden zich in Amsterdam Noord, een nieuw te ontwikkelen woongebied waar jonge hippe stadsbewoners naar toe moeten worden getrokken. De Shelltoren bijvoorbeeld.
Met zeventien verdiepingen, helikopterplatform en een prominente plek aan het IJ gaat deze toren twee clubs en een panoramarestaurant herbergen. Het vrijgeven van openingstijden moet bijdragen aan het imago van Amsterdam als wereldstad. Aan de andere kant zie je dat buurten waar van oudsher een bruisend nachtleven aanwezig was, strijden tegen de terreur van nieuwe bewoners met veel geld die klagen over geluidsoverlast en een ander soort horecagelegenheden in hun buurt prefereren boven nachtdiscotheken. Ook in andere Europese steden zijn soortgelijke ontwikkelingen gaande. In 2010 riep 'Le Monde' Parijs uit tot 'Europese hoofdstad van de verveling'.

\section{Uitgaan is alles behalve gezond en veilig en wil dat ook vaak niet zijn.}

Alternatieve uitgaanscircuits en subculturen hebben het zwaar te verduren in deze ontwikkeling en worden verdreven naar marginale plekken aan de rand van de stad. Sabina Rossignoli laat in haar bijdrage zien hoe Caribische feesten in de periferie van Parijs ervoor zorgen dat vooral vrouwelijke bezoeksters soms de grootste moeite hebben om überhaupt de dansvloer te bereiken. In Berlijn laat Kira Kosnick ons zien hoe een specifieke subcultuur, de Turkse LGTB (Lesbian, Gay, Transgender en Bisexual) uitgaansscene, in Kreuzberg het te verduren heeft onder druk van de gentrifiers die ander soortig uitgaansgelegenheden prefereren. Voor Britse Aziaten die 'Asian Parties' in Londen bezoeken is het niet zozeer de marginaliteit van de locatie. Veel feesten vinden plaats in het traditionele uitgaanshart van de stad; de West End. Op deze plek is het de uitsluiting en segregatie die plaatsvindt en zichtbaar wordt. Harpreet Cholia beschrijft hoe migranten met hun aanwezigheid bepaalde normen op plekken die traditioneel als 'wit' worden getypeerd kunnen 'verstoren'. Ook al leggen bepaalde groepen claims op gebruik van plekken in de nachtelijke stad de mate waarin ze worden geaccepteerd varieert nog steeds.

Ilse van Liempt (i.c.vanliempt@uu.nl) is werkzaam als universitair docent en onderzoeker bij het departement Sociale Geografie en Planologie aan de Universiteit Utrecht. Zij was als postdoc onderzoeker betrokken bij het onderzoeksproject 'Surveillance in Urban Nightscapes'. Irina van Aalst (i.vanaalst@ uu.nl) is aan dezelfde universiteit docent Stadsgeografie en projectleider van het onderzoeksproject 'Surveillance in Urban Nightscapes' (www.stadsnachtwacht.nl).

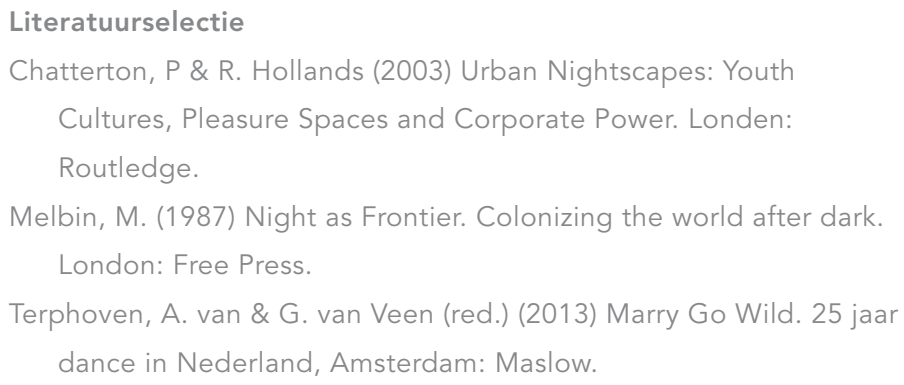

